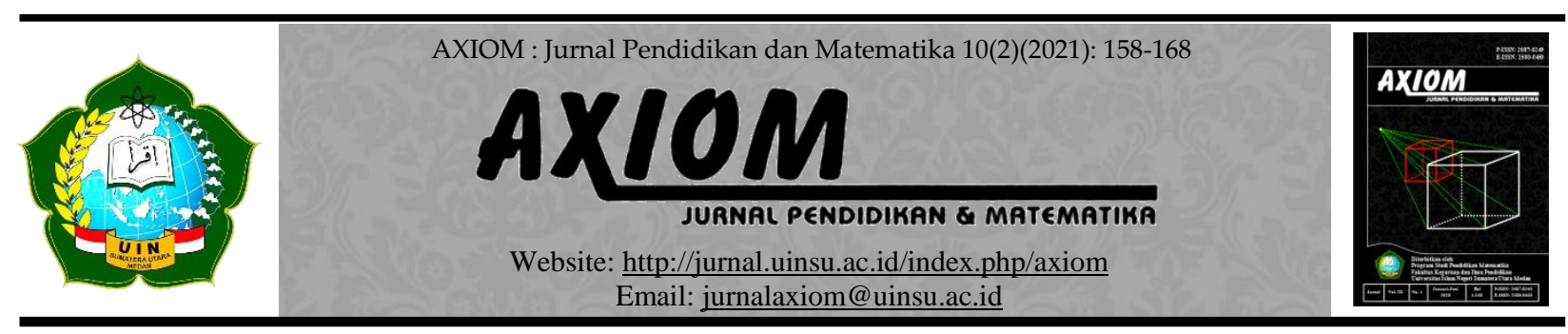

\title{
EFEKTIVITAS PRISMA LEKER WAIZ TERHADAP HASIL BELAJAR MATEMATIKA SISWA
}

Oleh:

\author{
Arinatul Aniza ${ }^{1}$, Tri Novita Irawati ${ }^{2}$, Sholahudin Al-Ayubi ${ }^{3}$ \\ ${ }_{1,2,3}$ Pendidikan Matematika, FKIP, Universitas Islam Jember \\ 1anizameili602@gmail.com, ${ }^{2}$ tri.novitairawati@gmail.com, ${ }^{3}$ sholahudin0679@gmail.com
}

doi : 10.30821/axiom.v10i2.9087

\begin{abstract}
Abstrak:
Pembelajaran berbasis online memiliki kendala yaitu siswa mengalami kesulitan belajar secara mandiri, salah satunya menunjukkan hasil belajar matematika yang tergolong rendah. Berpandangan pada kondisi tersebut memunculkan ide bagaimana cara mengajar matematika yang mudah dipahami siswa. Tujuan penelitian ini untuk mengetahui efektivitas PRISMA LEKER WAIZ terhadap hasil belajar matematika siswa. Jenis penelitian ini merupakan penelitian asosiatif dengan pendekatan kuantitatif. Desain penelitian yang digunakan one group pretest posttest design. Teknik pengumpulan data yang digunakan berupa tes dan dokumentasi. Adapun teknik analisis data meliputi beberapa tahapan diantaranya yaitu: uji validitas, uji reliabilitas, uji normalitas dan uji $t$. Hasil penelitian menunjukkan bahwa PRISMA LEKER WAIZ efektif terhadap hasil belajar matematika siswa. Dengan kata lain, PRISMA LEKER WAIZ dalam penelitian ini layak digunakan di masa pandemi karena media ini sudah dikembangkan sebelum penelitian, memiliki isi yang menarik (dilengkapi beragam bentuk latihan soal, kunci jawaban, desain menarik dan ringkasan materi), mudah diakses dalam pembelajaran online dan mudah dipahami siswa yaitu bisa mengerjakan soal matematika dengan baik menggunakan media ini.
\end{abstract}

Kata Kunci:

PRISMA LEKER WAIZ, Hasil Belajar

Abstract:

Online-based learning has problems, namely students have difficulty learning independently, one of which shows low mathematics learning outcomes. Looking at these conditions led to the idea of how to teach mathematics that is easy for students to understand. The purpose of this study was to determine the effectiveness of PRISMA LEKER WAIZ on students' mathematics learning outcomes. This type of research is an associative research with a quantitative approach. The research design used was one group pretest posttest design. Data collection techniques used in the form of tests and documentation. The data analysis technique includes several stages including: validity test, reliability test, normality test and t test. The results showed that PRISMA LEKER WAIZ was effective on students' mathematics learning outcomes. In other words, PRISMA LEKER WAIZ in this study is suitable for use during the pandemic because this media was developed prior to the research, has interesting content (equipped with various forms of practice questions, answer keys, attractive designs and material summaries), is easily accessible 
in online learning and It is easy for students to understand, that is, they can do math problems well using this media.

\section{Keywords:}

PRISMA LEKER WAIZ, Learning Outcomes

\section{A. Pendahuluan}

Hasil belajar siswa khususnya mata pelajaran matematika yang tergolong rendah mengakibatkan mutu pendidikan menurun (Aisyanah \& Kurniasari 2017). Mayoritas siswa mengeluh karena matematika dianggap sulit sehingga hasil belajar matematika belum memuaskan. Hal ini dikarenakan media pembelajaran yang digunakan guru kurang bervariasi (Aisyanah \& Kurniasari 2017). Hasil belajar matematika siswa yang tergolong kategori rendah dikarenakan kurangnya kemampuan pemecahan masalah. Hal tersebut terlihat saat siswa menghadapi soal matematika terbaru, di mana siswa tidak bisa menjelaskan cara penyelesaian seperti menentukan rumus dan cara yang akan digunakan untuk menyelesaikan masalah (Yusri, 2018).

Untuk mengatasi masalah tersebut, salah satu alternatif yang dapat digunakan dalam proses pembelajaran matematika adalah efektivitas penggunaan media pembelajaran berbasis masalah (Wulandari, Ruhiat, \& Nulhakim 2020). Media pembelajaran dibuat untuk membantu mengembangkan konsep siswa, mampu mengatasi rendahnya hasil belajar dan mampu memahami suatu materi. Oleh karena itu, pemilihan media pembelajaran yang tepat dan menarik diharapkan mampu meningkatkan hasil belajar sesuai dengan tujuan pembelajaran (Wulandari, Ruhiat, \& Nulhakim 2020).

Media pembelajaran di masa pandemi terdapat perubahan di mana menuntut para guru dapat menguasai media pembelajaran online yang mampu meningkatkan hasil belajar siswa. Pembelajaran online menjadi salah satu solusi untuk menghadapi kesulitan guru dan siswa dalam mengatasi pembelajaran secara langsung dimasa pandemi (Kusuma \& Hamidah 2020). Pembelajaran online dilakukan secara terpisah di luar kelas. Interaksi guru dan siswa yang dapat dilakukan dapat berupa mengirim pesan menggunakan beberapa aplikasi untuk mengumpulkan tugas yang telah diberikan (Rahmawati, 2016).

Oleh karena itu, guna mendukung pemerintah dalam proses pembelajaran online di masa pandemi, dikembangkanlah suatu alternatif media pembelajaran yang mendukung. Dalam pengembangannya, saat ini sudah banyak bermunculan aplikasi khusus yang digunakan sebagai platform untuk pembelajaran online, di antaranya adalah aplikasi whatsapp. Aplikasi whatsapp digunakan sebagai media chat digital yang mencakup whatsapp group, pesan teks, gambar, video, dan telepon. Aplikasi ini bertujuan untuk membantu masyarakat dalam menjalin komunikasi serta sebagai wadah diskusi untuk memecahkan berbagai masalah (Sidiq, 2019). Berdasarkan uraian tersebut maka dalam proses pembelajaran online yang menggunakan platform berupa aplikasi whatsapp dapat dikombinasikan dengan media pembelajaran yang menarik agar tidak mudah bosan. Salah satu alternatif media pembelajaran yang dapat digunakan adalah Lembar Kerja Siswa (LKS) disertai quiz (Wulandari et al., 2020).

Salah satu media pembelajaran yang dapat mendukung proses pembelajaran adalah LKS (Barlenti, Hasan, \& Mahidin 2017). Namun pada media LKS ini juga ditemukan beberapa kekurangan yaitu hanya memuat soal-soal evaluasi saja seperti pilihan ganda dan uraian, latihan soal yang sangat sedikit, ringkasan materi yang kurang jelas, tidak terdapat kunci jawaban, terlihat kurang menarik karena materi hanya disajikan berupa kalimat, desain LKS monoton dan kurang komunikatif karena terdapat beberapa gambar yang tidak dapat memperjelas pemahaman siswa (Barlenti et al., 2017). Penting adanya modifikasi media pembelajaran yang mayoritas digunakan di sekolah guna meningkatkan hasil belajar siswa sehingga dapat membantu siswa dalam memahami materi, memberikan semangat belajar, dan mengembangkan kemampuannya (Irawati, 2016). Dengan demikian, dalam penelitian ini didesain media LKS disertai quiz online yang mudah dipahami siswa, mampu meningkatkan hasil belajar, dan menarik minat belajar siswa. Perbedaanya dengan LKS lain yaitu terletak pada kompetensi inti, kompetensi dasar, 
indikator pencapaian kompetensi, tujuan pembelajaran, peta konsep, ringkasan materi, permasalahan, contoh dan 6 jenis latihan soal yang dilengkapi kunci jawaban.

Selain media pembelajaran berupa LKS dalam penelitian ini juga dilengkapi quiz online agar mampu memberi semangat belajar dan meningkatkan hasil belajar siswa (Irawati, 2016). Quiz online yang digunakan dalam penelitian ini berbantuan smartphone dan komputer. Menurut Siskawati (2018) penggunaan smartphone dan computer dalam pembelajaran memberikan banyak keutamaan yaitu: (1) mampu merangsang pikiran, perasaan, minat serta perhatian siswa; (2) proses pembelajaran akan lebih efektif karena memungkinkan teratasinya hambatan dalam proses komunikasi antara guru dengan siswa; (3) efektivitas belajar yang memiliki persentase tinggi yaitu ketika belajar dilakukan dengan melihat dan mendengar serta yang paling tinggi yaitu ketika siswa melakukan sendiri apa yang dipelajarinya.

Irawati (2016) mendefinisikan bahwa quiz online merupakan tes yang dilakukan dengan bantuan smartphone atau komputer disertai jaringan internet. Rahmawati (2016) menyebutkan bahwa tes dapat dibagi menjadi 3 jenis, yaitu tes tertulis, tes lisan, dan tes perbuatan. Tes tertulis terdiri dari dua bentuk, yaitu uraian dan objektif. Dalam pengembang media PRISMA LEKER WAIZ (Paket Ringkasan Materi dengan Lembar Kerja Siswa beserta Quiz), peneliti sudah menggunakan LKS disertai quiz online yang berbantuan aplikasi proprofs. Aplikasi ini mencakup 5 jenis latihan soal berdasarkan bentuk tes tertulis yaitu menjodohkan, pilihan ganda, jawaban singkat, benar salah, dan melengkapi (Siskawati, 2018). Aplikasi ini merupakan aplikasi online yang disajikan dalam bentuk website dan dapat diunduh pada play store. Aplikasi ini terbagi menjadi dua bagian yaitu free trial dan premium dengan perbedaan keduanya terlihat pada batasan fasilitasnya (Wijaya, 2018)

Berdasarkan pemaparan di atas maka selama proses pembelajaran online sangat diperlukan suatu media pembelajaran yang dapat meningkatkan hasil belajar siswa tanpa mengganggu kondisi psikologisnya. Banyak sekali permasalahan yang dialami siswa seperti bosan, jenuh, malas belajar, hasil belajar yang rendah, sulit menyelesaikan soal, sulit memahami materi matematika, namun dengan adanya aplikasi proprofs ini mampu mengatasi permasalahan tersebut yaitu siswa diberikan quiz online (Wijaya, 2018). Selain itu, media pembelajaran berupa LKS juga dapat mendukung proses pembelajaran untuk menambah minat belajar seperti mengerjakan soal dan memahami konsep materi (Barlenti et al., 2017). Adapaun media pembelajaran yang akan digunakan dalam penelitian ini merupakan perpaduan antara LKS elektronik dan quiz online yang bernama PRISMA LEKER WAIZ. Berpandangan pada kondisi tersebut membuat peneliti semakin tertarik untuk mengetahui efektivitas PRISMA LEKER WAIZ terhadap hasil belajar matematika siswa.

\section{B. Kajian Teoritis}

\section{Hasil Belajar Matematika}

Sudjana (2019) mendefinisikan bahwa hasil belajar adalah kemampuan yang dimiliki siswa setelah menerima pengalaman belajar. Menurut Sani (2019) menyatakan bahwa hasil belajar adalah perubahan perilaku atau kompetensi (sikap, pengetahuan, keterampilan) yang diperoleh siswa setelah melalui aktivitas belajar. Definisi lain mengatakan bahwa hasil belajar merupakan suatu proses untuk melihat sejauh mana siswa dapat menguasai pembelajaran setelah mengikuti proses belajar mengajar (Kustandi and Darmawan, 2020). Berdasarkan beberapa pengertian di atas dapat disimpulkan bahwa hasil belajar merupakan ukuran tingkat keberhasilan yang dapat dicapai oleh siswa dari proses belajar serta menyebabkan terjadinya perubahan tingkah laku berupa kognitif, afektif, dan psikomotorik.

Hamzah (2014) berpendapat bahwa matematika adalah pengetahuan struktur yang terorganisasi, sifat-sifat dalam teori dibuat secara deduktif berdasarkan kepada unsur yang tidak didefinisikan, aksioma, sifat atau teori yang telah dibuktikan kebenarannya. Menurut Shadiq (2018) menyatakan bahwa matematika adalah bahasa, sebab matematika merupakan bahasa simbol yang berlaku secara universal dan sangat padat makna. Definisi lain mengatakan bahwa matematika adalah ilmu deduktif, ilmu tentang pola keteraturan, seni, bahasa, ilmu tentang 
struktur yang terorganisasi (Isrok'atun and Rosmala, 2019). Berdasarkan uraian pengertian matematika dari beberapa pendapat ahli di atas, dapat disimpulkan bahwa matematika merupakan ilmu pengetahuan yang terstruktur dan terorganisasi, memiliki banyak makna, sifatsifat dalam teori dibuat secara deduktif berdasarkan teori yang telah dibuktikan kebenaranya.

Berdasarkan penjelasan tersebut peneliti menyimpulkan bahwa hasil belajar matematika merupakan suatu perubahan tingkah laku berupa kognitif, afektif, dan psikomotorik yang merujuk pada pemberian ilmu pengetahuan yang terstruktur dan terorganisasi, memiliki banyak makna, sifat-sifat dalam teori dibuat secara deduktif berdasarkan teori yang telah dibuktikan kebenaranya pada proses pembelajaran. Namun pembelajaran matematika online dimasa pandemi hasil belajar yang dapat dilihat maupun dihitung adalah hasil belajar pada ranah kognitif yang berkenaan dengan hasil belajar intelektual.

\section{PRISMA LEKER WAIZ}

Berdasarkan hasil pengembangan dalam penelitian yang telah dilakukan oleh Aniza dan Siskawati (2020), PRISMA LEKER WAIZ (Paket Ringkasan Materi dengan Lembar Kerja Siswa beserta Quiz) dirancang menjadi dua bagian yaitu LKS elektronik dan quiz online. Bagian pertama yaitu LKS elektronik berisi identitas (nama mata pelajaran, kelas/semester, materi pokok, alokasi waktu, KI, KD, IPK, dan tujuan pembelajaran), peta konsep, ringkasan materi 4 pertemuan, isi modul disusun mengikuti pendekatan saintifik (mengamati, menanya, menggali informasi dan contoh), dan ada 6 jenis latihan soal (menjodohkan, pilihan ganda, jawaban singkat, benar salah, melengkapi, dan uraian) beserta kunci jawaban. Selain itu, lembar kerja siswa (LKS) elektronik ini dirancang dengan ukuran berstandar ISO yakni ukuran A4 (210× $297 \mathrm{~mm}$ ), isi LKS menggunakan format penulisan font Times New Roman, font size 12, line and paragraph spacing 1.15. Kemudian, bagian sampul dari LKS didesain fullcolour agar mampu menarik perhatian siswa. Berdasarkan penjelasan di atas dapat dilihat pada Gambar 1.

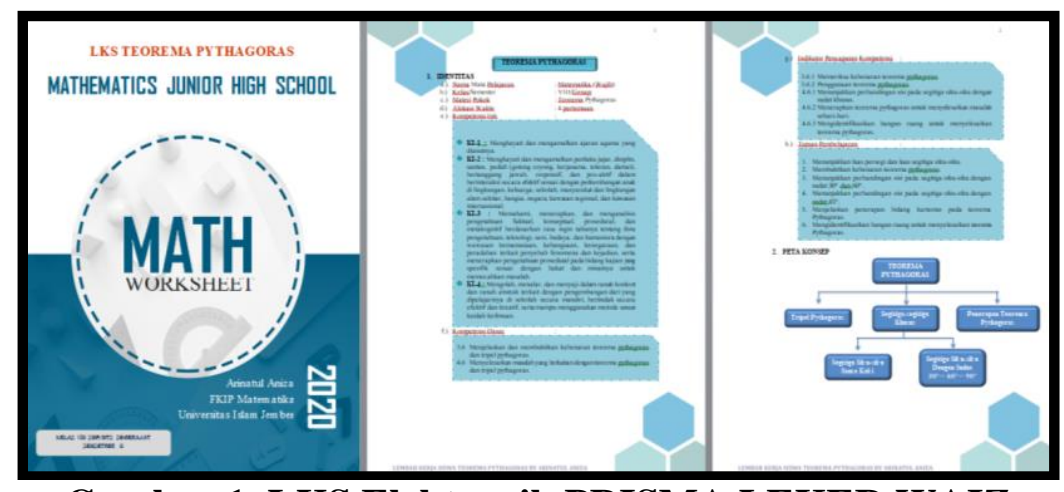

Gambar 1. LKS Elektronik PRISMA LEKER WAIZ

Bagian kedua adalah bagian utama yaitu quiz online PRISMA LEKER WAIZ yang dirancang berbasis aplikasi proprofs quiz maker yang dapat di akses melalui website dan playstore. Hal ini dilakukan karena aplikasi proprofs quiz maker mudah digunakan baik dengan handphone atau computer sehingga dapat memudahkan siswa dalam memainkan quiz online tersebut. Selain itu pada quiz online berisi 5 jenis latihan soal (menjodohkan, pilihan ganda, jawaban singkat, benar salah, dan melengkapi) beserta kunci jawaban. Setiap quiz online dibedakan dengan 4 cover yang berfungsi mempermudah siswa dalam membedakan kuis pertemuan pertama, kedua, ketiga, dan keempat. Berdasarkan penjelasan bagian kedua quiz online PRISMA LEKER WAIZ dapat dilihat pada Gambar 2. 


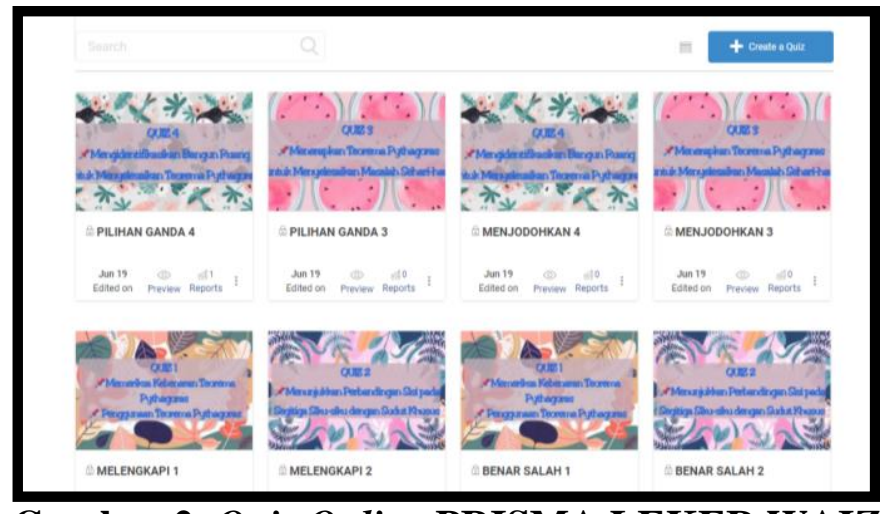

Gambar 2. Quiz Online PRISMA LEKER WAIZ

Media ini dikembangkan berdasarkan materi pythagoras dengan kompetensi dasar dan indikator pencapaian kompetensi sebagai berikut:

Tabel 1. Kompetensi Dasar dan Indikator Pencapaian Kompetensi

Kompetensi Dasar Pengetahuan

3.6 Menjelaskan dan membuktikan kebenaran teorema pythagoras dan tripel pythagoras.

\section{IPK Pengetahuan}

3.6.1 Memeriksa kebenaran teorema pythagoras.

3.6.2 Penggunaan teorema pythagoras.

\section{Kompetensi Dasar Keterampilan}

4.6 Menyelesaikan masalah yang berkaitan dengan teorema pythagoras dan tripel pythagoras.

\section{Sumber : Aniza \& Siskawati (2020)}

\section{IPK Keterampilan}

4.6.1 Menunjukkan perbandingan sisi pada segitiga siku-siku dengan sudut khusus.

4.6.2 Menerapkan teorema pythagoras untuk menyelesaikan masalah sehari-hari.

4.6.3 Mengidentifikasikan bangun ruang untuk menyelesaikan teorema pythagoras.

Media ini juga memiliki tujuan pembelajaran yang telah disesuaikan dengan materi pythagoras yaitu: (1) Menunjukkan luas persegi dan luas segitiga siku-siku, (2) Membuktikan kebenaran teorema Pythagoras, (3) Menunjukkan perbandingan sisi pada segitiga siku-siku dengan sudut $30^{\circ}$ dan $60^{\circ}$, (4) Menunjukkan perbandingan sisi pada segitiga siku-siku dengan sudut $45^{\circ}$, (5) Menjelaskan penerapan bidang kartesius pada teorema Pythagoras, dan (6) Mengidentifikasikan bangun ruang untuk menyelesaikan teorema Pythagoras.

\section{Metode Penelitian}

\section{Jenis Penelitian}

Penelitian ini menggunakan jenis penelitian asosiatif dengan pendekatan kuantitatif. Desain penelitian yang digunakan adalah one group pretest posttest design dimana dalam rancangan ini digunakan satu kelompok sampel (Suryabrata, 2011). Selain itu, dikarenakan tidak menggunakan kelompok kontrol penelitian ini merupakan penelitian pre-eksperimental. Adapun desain dalam penelitian ini dapat dilihat pada Gambar 3.

\begin{tabular}{|ccc|}
\hline Pretest & Treatment & Prosttes \\
\hline $\boldsymbol{T}_{\mathbf{1}}$ & $\mathbf{X}$ & $\boldsymbol{T}_{\mathbf{2}}$ \\
\hline
\end{tabular}

Gambar 3. One Group Pretest Posttest Design 


\section{Waktu dan Tempat Penelitian}

Waktu dan tempat dalam penelitian ini dilaksanakan mulai tanggal 5 Januari hingga 20 Januari 2021 jam 07.30 - 09.30 WIB di SMPN 1 Ambulu. Dalam LKS tertera 4 pertemuan namun pihak sekolah hanya memberikan waktu 2 pertemuan. Setiap 1 pertemuan terdapat alokasi waktu 2 JP.

\section{Populasi dan Sampel Penelitian}

Populasi dalam penelitian ini adalah seluruh siswa SMPN 1 Ambulu tahun ajaran 2020/2021. Sampel yang digunakan merupakan siswa kelas VIIIA SMPN 1 Ambulu semester genap tahun ajaran 2020/2021 yang terdiri dari siswa putri sebanyak 22 orang dan siswa putra sebanyak 10 orang. Pengambilan sampel secara acak yaitu menggunakan simple random sampling (pengambilan sampel acak sederhana).

\section{Prosedur Penelitian}

Prosedur penelitian yang digunakan dalam penelitian ini mengambil sumber dari (Siskawati, 2018). Adapun diagram alur prosedur dalam penelitian ini akan dijelaskan melalui Gambar 4.

\section{Data, Instrumen, dan Teknik Pengumpulan Data}

Data yang dikumpulkan merupakan nilai hasil belajar matematika pretest dan posttest. Instrumen penelitian yaitu menggunakan media PRISMA LEKER WAIZ yang terdiri dari LKS elektronik dan quiz online. Teknik pengumpulan data berupa tes dan dokumentasi.

\section{Teknik Analisis Data}

Teknik analisis data yang digunakan meliputi uji validitas, uji reliabilitas, uji normalitas dan uji hipotesis penelitian (uji $t$ ). Berdasarkan data yang telah diperoleh dalam penelitian ini, kemudian di hitung menggunakan aplikasi SPSS versi 20. Hasil perhitungan tersebut saling berkaitan sesuai alur prosedur penelitian. Hasil uji hipotesis penelitian dapat digunakan untuk menjawab tujuan penelitian. Hipotesis penelitian ini berupa $H_{a}$ (PRISMA LEKER WAIZ efektif digunakan untuk meningkatkan hasil belajar matematika siswa) dan $H_{o}$ (PRISMA LEKER WAIZ tidak efektif digunakan untuk meningkatkan hasil belajar matematika siswa). Adapun kriteria pengambilan kesimpulan uji $t$ diantaranya meliputi: (1) jika sig $>\alpha H_{o}$ diterima $H_{a}$ di tolak maka tidak efektif; (2) jika sig $<\alpha H_{a}$ diterima $H_{o}$ di tolak maka efektif; (3) dimana $\alpha$ yang digunakan berupa 0.05 .

Kemudian dilakukan uji validitas dan reliabilitas terhadap instrumen yang digunakan dalam penelitian ini. Uji validitas digunakan untuk mengetahui apakah setiap butir dalam instrumen itu valid (Sugiyono, 2014). Hipotesis uji validitas yaitu $H_{1}$ (soal nomor 1 sampai 10 valid) dan $\mathrm{H}_{2}$ (soal nomor 1 sampai 10 tidak valid). Bandingkan satu per satu dari keseluruhan soal, peneliti akan menampilkan salah satu data seperti soal nomor 1 , sig. 2 tailed $=0.004$ dan $\alpha=0.05$. Jadi, sig. 2 tailed $<\alpha$ maka $H_{1}$ diterima $H_{2}$ ditolak dapat disimpulkan soal nomor 1 valid. Berdasarkan data input SPSS soal nomor 1-10 dikatakan valid karena fakta menunjukkan nilai sig. 2 tailed $<\alpha$.

Uji reliabilitas digunakan untuk mengetahui apakah setiap butir dalam instrumen itu reliabel (Sugiyono, 2018). Hipotesis uji reliabilitas yaitu $H_{x}$ (soal nomor 1 sampai 10 reliabel) dan $H_{y}$ (soal nomor 1 sampai 10 tidak reliabel). Kemudian hasil uji reliabilitas menunjukkan besar nilai cronbach's alpha $=0.958$ dan besar nilai product moment $=0.632$. Berdasarkan hasil uji tersebut maka cronbach's alph $>$ product moment jadi, $H_{x}$ diterima $H_{y}$ ditolak dapat disimpulkan dari 10 soal tersebut reliabel. 


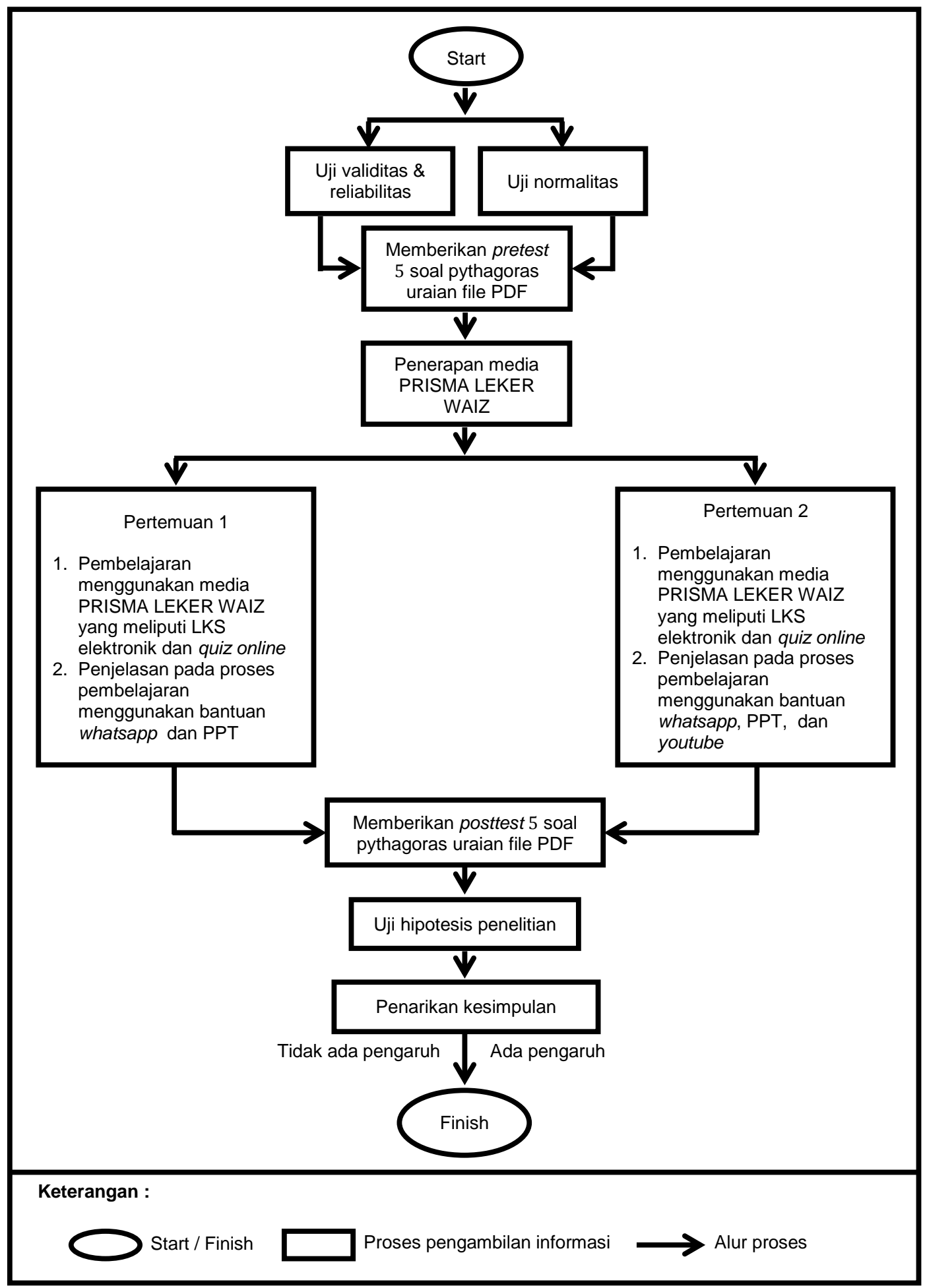

Gambar 4. Diagram Alur Prosedur Penelitian

\section{Hasil Penelitian dan Pembahasan}

\section{Hasil}

Hasil belajar pretest kelas VIIIA dapat dilihat pada Tabel 2. Hasil belajar pretest kelas VIIIA tersebut akan digunakan untuk menghitung uji normalitas. Hipotesis uji ini yaitu $H_{i}$ (sampel berasal dari populasi normal) dan $H_{j}$ (sampel berasal dari populasi tidak normal). Hasil input data nilai pretest ke aplikasi SPSS dapat dilihat pada Tabel 3. 
Tabel 2. Hasil Belajar Pretest Kelas VIIIA

\begin{tabular}{cccc}
\hline Nama & Nilai & Nama & Nilai \\
\hline A W O W & 80 & L M S & 58 \\
A K & 77 & L S P R & 100 \\
A R L & 75 & M A L & 92 \\
A D D & 35 & M A R & 70 \\
A V H & 0 & M D F & 50 \\
A A S & 76 & M V M M & 56 \\
A A S & 75 & M N H & 40 \\
B O P & 100 & N N & 78 \\
C A N & 76 & N R D F & 46 \\
C S P & 78 & N S A & 50 \\
D A M & 75 & R E & 62 \\
E M & 50 & T N N F & 90 \\
F A F & 62 & Y N D & 90 \\
H H A & 52 & Z A S & 29 \\
I A A & 79 & & 75 \\
L C A S & 60 & & 80 \\
\hline
\end{tabular}

Tabel 3. Uji Normalitas

\begin{tabular}{cccccccc}
\hline & \multirow{2}{*}{ Kelas } & \multicolumn{2}{c}{ Kolmogorov-Smirnov $^{\text {a }}$} & \multicolumn{3}{c}{ Shapiro-Wilk } \\
\cline { 2 - 9 } & Statistic & Df & \multicolumn{1}{c}{ Sig. } & Statistic & df & \multicolumn{1}{c}{ Sig. } \\
\hline Nilai & 1 & .190 & 32 & .005 & .937 & 32 & .061 \\
\hline
\end{tabular}

a. Lilliefors Significance Correction

Tabel 3 menunjukkan uji normalitas besar sig. Shapiro-willk $=0.061$ dan $\alpha=0.05$. Berdasarkan hasil uji normalitas maka $\operatorname{sig}>\alpha$ jadi, $H_{i}$ diterima $H_{j}$ ditolak dapat disimpulkan sampel yang diambil berasal dari populasi normal. Dari hasil uji normalitas dapat menentukan rumus yang digunakan berupa rumus statistik parametris (paired sample $t$ test) (Trihendradi, 2013).

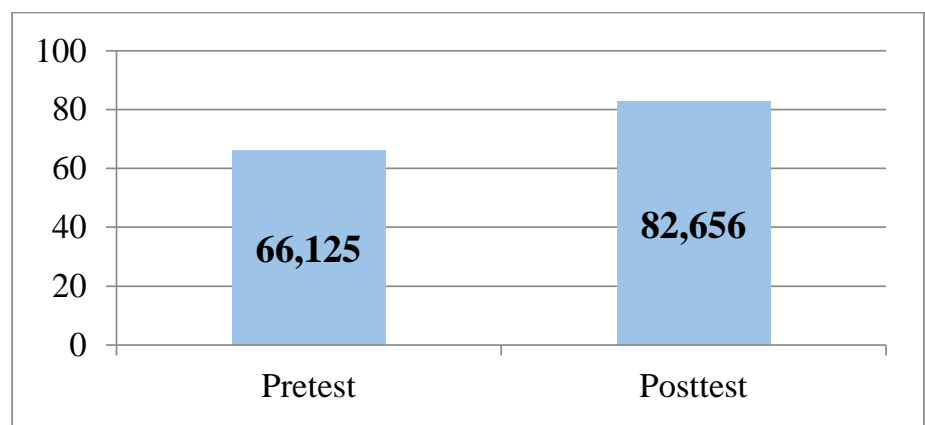

\section{Gambar 5. Perbandingan Pretest dan Posttest Kelas VIIIA}

Hasil perbandingan rata-rata nilai pretest dan posttest di atas akan digunakan untuk menghitung uji hipotesis penelitian yaitu menggunakan paired sample $t$ test. Uji hipotesis penelitian merupakan hipotesis yang dirumuskan untuk menjawab permasalahan yang ada di lapangan (Sugiyono, 2014). Hipotesis penelitian ini yaitu $H_{a}$ (PRISMA LEKER WAIZ efektif digunakan untuk meningkatkan hasil belajar matematika siswa) dan $H_{o}$ (PRISMA LEKER WAIZ tidak efektif digunakan untuk meningkatkan hasil belajar matematika siswa). Hasil input data nilai perbandingan ke aplikasi SPSS ditampilkan pada Tabel 4. 


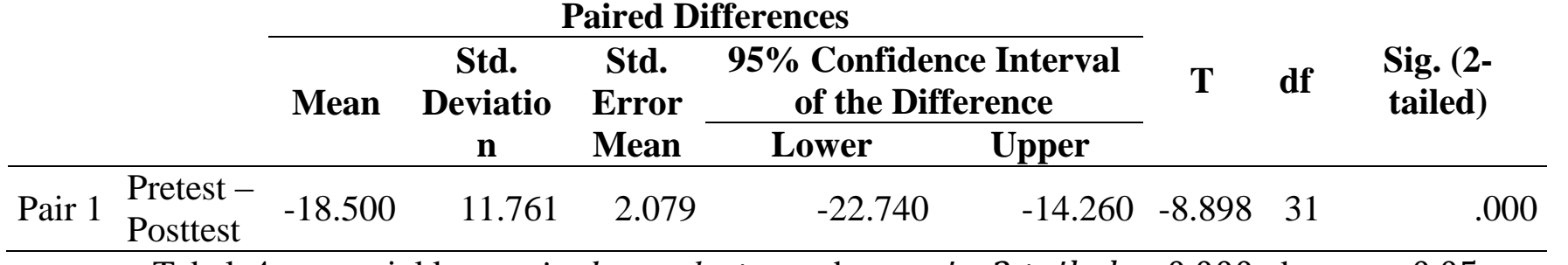

Tabel 4 menunjukkan paired sample $t$ test besar sig. 2 tailed $=0.000$ dan $\alpha=0.05$. Berdasarkan hasil uji tersebut maka sig. 2 tailed $<\alpha$ jadi, $H_{a}$ diterima $H_{o}$ ditolak dapat disimpulkan PRISMA LEKER WAIZ efektif digunakan untuk meningkatkan hasil belajar matematika siswa.

\section{Pembahasan}

Selama pelaksanaan pembelajaran berlangsung peneliti menerapkan media PRISMA LEKER WAIZ yang telah di kembangkan. Hal tersebut bertujuan untuk mengetahui apakah media tersebut efektif meningkatkan hasil belajar matematika siswa. Di awal pertemuan peneliti melakukan perkenalan, penjelasan terkait selama proses pembelajaran dan diberikan soal pretest pada siswa kelas VIIIA dengan waktu pengerjaan 1 jam menggunakan aplikasi whatsapp. Selanjutnya, peneliti melakukan penerapan media PRISMA LEKER WAIZ sebanyak 2 pertemuan dan alokasi waktu 2 JP dengan menggunakan aplikasi whatsapp.

Pertemuan 1 dengan alokasi waktu jam 08.30 - 09.30 WIB, guru menyediakan PPT dan memberi penjelasan melalui whatsapp group. Kemudian siswa di minta mempelajari materi pythagoras dalam PPT tersebut. Setelah itu siswa mengamati permasalahan, menanya, dan menggali informasi yang telah disediakan di LKS elektronik. Untuk mengasah kemampuan siswa pada pertemuan pertama bisa mengerjakan quiz online yang telah disediakan.

Pertemuan 2 dengan alokasi waktu jam 08.30 - 09.30 WIB, guru menyediakan video penjelasan via youtube. Kemudian siswa di minta mempelajari materi pythagoras yang tersedia di dalam video tersebut. Setelah itu siswa mengamati permasalahan, menanya, dan menggali informasi yang telah disediakan di LKS elektronik. Untuk mengasah kemampuan siswa pada pertemuan kedua bisa mengerjakan quiz online yang telah disediakan.

Di akhir pertemuan diberikan soal posttest dengan waktu pengerjaan 1 jam menggunakan aplikasi whatsapp. Hasil belajar siswa selama menggunakan media PRISMA LEKER WAIZ yang diukur dari perbandingan rata-rata nilai pretest dan posttest menunjukkan peningkatan yang signifikan yaitu 66.125 ke 82.656 dapat dilihat pada Gambar 5. Selanjutnya, hasil uji hipotesis penelitian dari nilai pretest dan posttest siswa kelas VIIIA dapat dikatakan bahwa PRISMA LEKER WAIZ efektif digunakan untuk meningkatkan hasil belajar matematika. Hal tersebut di tunjukkan dengan besar nilai sig. 2 tailed $<\alpha$ maka $H_{a}$ diterima $H_{o}$ ditolak. Sehingga peneliti dapat menjawab tujuan penelitian yaitu PRISMA LEKER WAIZ efektif digunakan untuk meningkatkan hasil belajar matematika. Pengamatan selama proses pembelajaran berlangsung memunculkan alasan utama mengapa hasil belajar siswa meningkat. Hal tersebut karena siswa tertantang dengan adanya beragam jenis soal maupun adanya nilai berupa sertifikat. Jika nilai mereka jelek akan merasa malu saya harus lebih baik lagi dari pada siswa lainnya.

Berdasarkan pemaparan tersebut peneliti mampu mengatasi masalah yang dialami siswa melalui penyediaan media PRISMA LEKER WAIZ yang dilengkapi beragam jenis latihan soal beserta kunci jawaban. Siskawati (2018) mengatakan bahwa dengan adanya beragam jenis latihan soal mampu memberi motivasi untuk belajar mandiri yang lebih dari sebelumnya. Hal tersebut dikarenakan jika tidak disediakan oleh guru maka siswa cenderung tidak mau mencari. Kemudian sebagai usaha untuk menarik minat siswa agar mau belajar, maka soal akan ditampilakan dalam smartphone dan computer yang berbantuan aplikasi proprofs. Namun ketika siswa diberi kesempatan belajar mandiri maka tidak semua siswa yang antusias untuk bersedia mengerjakan, sebagai usaha mengantisispasinya kuis tersebut diberi nilai yang nantinya akan menjadi salah satu bagian dari nilai akhir siswa kelas VIIIA. 
Dengan demikian maka dapat dikatakan bahwa media PRISMA LEKER WAIZ layak digunakan selama pembelajaran online di masa pandemi. Penelitian ini juga dikatakan berhasil karena PRISMA LEKER WAIZ efektif digunakan untuk meningkatkan hasil belajar matematika siswa. Selama pelaksaan pembelajaran menggunakan media PRISMA LEKER WAIZ muncul beberapa kelebihan dan kekurang yang dapat kita gunakan sebagai berikut. Kelebihan media ini yaitu: (1) mudah diakses selama pembelajaran online maupun offline; (2) mudah dipahami siswa karena siswa mampu mengerjakan soal dengan baik; (3) terdapat kunci jawaban untuk memudahkan siswa maupun guru dalam mengoreksi; (4) media ini sudah dikembangkan dan prosiding; (5) memiliki isi yang menarik seperti dilengkapi beragam bentuk latihan soal, ringkasan materi dan menampilkan nilai siswa melalui sertifikat. Kekurangannya yaitu: (1) terkendala sinyal jika terdapat gangguan; (2) siswa yang sangat malas susah diminta tugas atau jawaban; (3) jika siswa tidak diminta cara penyelesaian maka mereka cenderung melihat kunci jawaban; (4) media ini hanya menggunakan free trial sehingga quiz online kurang maksimal.

\section{E. Simpulan}

Berdasarkan pemaparan hasil dan pembahasan di atas maka dapat dikatakan adanya pembuatan LKS elektronik dan quiz online sebagai media pembelajaran sangat efektif terhadap hasil belajar matematika siswa dan media PRISMA LEKER WAIZ layak digunakan dalam pembelajaran online. Hasil tersebut diperkuat dengan adanya hasil uji hipotesis penelitian yang menunjukkan sig $=0.000$ dan $\alpha=0.05$ dimana sig $<\alpha$ maka $H_{a}$ diterima $H_{o}$ ditolak. Oleh karena itu, hasil uji hipotesis penelitian tersebut dapat menjawab tujuan penelitian yaitu PRISMA LEKER WAIZ efektif digunakan untuk meningkatkan hasil belajar matematika siswa.

\section{DAFTAR PUSTAKA}

Aisyanah, N., and Kurniasari, Z. (2017). Pengaruh Model Pembelajaran Problem Based Learning dengan Strategi Alat Peraga Puzzle Dadu terhadap Minat Belajar dan Hasil Belajar Matematika Siswa Kelas VIII Materi Peluang SMPN 1 Sumbergempol Tulungagung Tahun Ajaran 2017/2018. JKPM (Jurnal Kajian Pendidikan Matematika), 3(1), 33-44.

Aniza, A., and Siskawati, F. S. (2020). Pengembangan "PRISMA LEKER WAIZ" Sebagai Bahan Ajar di Masa Pandemi. Theta: Jurnal Pendidikan Matematika, 2(2), 68-75.

Barlenti, I., Hasan, M., and Mahidin, M. (2017). Pengembangan LKS Berbasis Project Based Learning. Jurnal Pendidikan Sains Indonesia (Indonesian Journal of Science Education), 5(1), 81-86.

Hamzah, A. (2014). Evaluasi Pembelajaran Matematika. Jakarta: Rajagrafindo Persada.

Irawati, T. N. (2016). Pengembangan Paket Tes Kemampuan Penalaran Proporsional Siswa $S M P$. Jember: Universitas Jember.

Isrok'atun, I., and Rosmala, A. (2019). Model-model pembelajaran matematika (B. S. Fatmawati, Ed.). Jakarta: Bumi Aksara.

Kustandi, C., and Darmawan, D. (2020). Pengembangan Media Pembelajaran: Konsep \& Aplikasi Pengembangan Media Pembelajaran bagi Pendidik di Sekolah dan Masyrakat. Jakarta: Prenadamedia Group.

Kusuma, J. W., and Hamidah, H. (2020). Perbandingan Hasil Belajar Matematika Dengan Penggunaan Platform Whatsapp Group Dan Webinar Zoom Dalam Pembelajaran Jarak Jauh Pada Masa Pandemik Covid 19. JIPMat (Jurnal Ilmiah Pendidikan Matematika), 5(1), 97-106. https://doi.org/10.26877/jipmat.v5i1.5942

Rahmawati, I. (2016). Rahmawati, I. (2016). Pelatihan dan pengembangan pendidikan jarak jauh berbasis digital class platform edmodo. Prosiding Temu Ilmiah Nasional Guru (TING) VIII UT, 9. Prosiding Temu Ilmiah Nasional Guru (TING) VIII, 411-419.

Sani, R. A. (2019). Strategi belajar mengajar. Depok: Rajagrafindo Persad.

Shadiq, F. (2018). Pembelajaran Matematika : Cara Meningkatkan Kemampuan Berpikir Siswa. Bandung: Graha Ilmu. 
Sidiq, R. (2019). Pemanfaatan Whatsapp Group dalam Pengimplementasian Nilai-Nilai Karakter Pancasila pada Era Disrupsi. Puteri Hijau: Jurnal Pendidikan Sejarah, 4(2), 145-154.

Siskawati, F. S. (2018). Pengembangan "PAKSOBRI" dengan Quiz Faber Mata Kuliah Aljabar Linier Elementer di Universitas Islam Jember. Gammath: Jurnal Ilmiah Program Studi Pendidikan Matematika, 3(2), 26-37.

Sudjana, N. (2019). Penilaian hasil proses belajar mengajar. Bandung: Remaja Rosdakarya.

Sugiyono. (2014). Metode Penelitian kuantitatif, kualitatif dan $R \&$ D. Bandung: Alfabeta.

Suryabrata, S. (2011). Metodologi Penelitian. Jakarta: Rajagrafindo Persada.

Trihendradi, C. (2013). Langkah Mudah Menguasai SPSS 21. Yogyakarta: Andi.

Wijaya, J. (2018). Pemanfaatan aplikasi Daring Proprofs Quiz Maker untuk mengembangkan kegiatan apersepsi pembelajaran matematika topik trigonometri kelas X IPA SMA Marsudirini Sedes Sapientiae Semarang tahun ajaran 2017/2018. Sanata Dharma University.

Wulandari, Y., Ruhiat, Y., and Nulhakim, L. (2020). Pengembangan Media Video Berbasis Powtoon pada Mata Pelajaran IPA di Kelas V. Jurnal Pendidikan Sains Indonesia (Indonesian Journal of Science Education), 8(2), 269-279. https://doi.org/10.24815/jpsi.v8i2.16835

Yusri, A. Y. (2018). Pengaruh Model Pembelajaran Problem Based Learning Terhadap Kemampuan Pemecahan Masalah Matematika Siswa Kelas VII Di SMP Negeri Pangkajene. Mosharafa: Jurnal Pendidikan Matematika, 1, 51-62. 